\title{
AOR
}

Selected Papers of \#AoIR2020:

The 22nd Annual Conference of the

Association of Internet Researchers

Virtual Event / 13-16 Oct 2021

\section{PASSION, PIPELINES, AND PRECARITY: WORKING LIVES IN GAMES FROM THE PERSPECTIVE OF HIGHER EDUCATION}

\author{
Alison Harvey \\ University of Leicester \\ Introduction: Future gamesworker identities
}

For years, academics and journalists have proclaimed a crisis of gameswork, detailing the 'destruction' of the lives of those in this creative workforce, and wondering when the 'breaking point' of professional game design, premised on crunch, work limbo, and churn, would come. Still it was only fairly recently, at the March 2018 Game Developers Conference, typically a heavily corporatized event, that a large-scale discussion of unionization was staged, leading to the formation of Game Workers Unite. While collective organizing in games is going global, with branches forming from France to Australia to South Korea, these developments are outpaced by increasingly transnational dynamics of outsourcing and automation (Fung, 2016; Hunteman \& Aslinger, 2013; Kerr, 2016), threatening to devalue and even eliminate already highlycompetitive jobs in 'cool industries' of 'passionate' workers (Neff, Wissinger \& Zukin, 2005).

This paper considers these global contradictions and tensions through analysis of a group heavily implicated in visions of the future of gameswork- students in formal games education. While within game studies there has been sustained interest in the production of this form and labour relations therein, the shape and role of games higher education remains underexplored. The existing scholarship indicates that these formal sites of training tend to cultivate the still-largely young, male, and passionate fanworkforce on which games depend (Deuze, Martin \& Allen, 2007; Consalvo, 2008; Chia, 2019). Furthermore, these contexts are vital in the formation of future gamesworker identities that are conservative, uncritical, and risk-adverse, despite pervasive discourses of creativity and innovation linked to them (Harvey, 2019). Vitally, however, the question of how these norms relate to shifting work realities has yet to be explored.

Suggested Citation (APA): Harvey, A. (2021, October). Passion, Pipelines, and Precarity: Working Lives in Games from the Perspective of Higher Education. Paper presented at AolR 2021: The 22nd Annual Conference of the Association of Internet Researchers. Virtual Event: AolR. Retrieved from http://spir.aoir.org. 


\section{Discourses of diverse talent in games}

Despite the relative lack of research, the higher educational context and the role students as future working subjects play within not only the games workforce but the creative industries more broadly is significant. As subjects within games discourse, students in higher education are symbolically and discursively important, representing to policy-oriented stakeholders the promise of the national industry's growth, productivity, and sustainability in the form of 'talent' (Livingstone \& Hope, 2011). Here, higher education institutions (HEI) are seen as important sites for addressing 'skills shortages' and acting as 'feeders' of human capital to the sector. National industries become 'talent hubs' while educators must concern themselves with watertight 'talent pipelines' enabling large 'talent pools'. The legibility of this approach to gamesworkers before their entry into the industry can be seen in the ongoing dominance of the talent discourse across the mission statements and activities of major trade bodies such as UKIE, advocacy groups including European Women in Games and BAME (Black, Asian, and Minority Ethnic) in Games, and charity organizations like the British Games Institute, which has to date organized two summits focused on games education.

Talent discourse is also not distinct from discussion of a still male dominated industrydocuments referencing talent in games often affix 'diverse' before the term, communicating awareness of distinctly homogenous workforces while placing responsibility on educational institutions to address pernicious exclusion. Overall, the variable metaphors that become attached to 'talent' provide a set of images and discourses productive of flows of capital in the British context as demonstrated by the Transfuzer and UK Games Fund programmes. Simultaneously, it is a perspective that simplifies and flattens the experiences, contexts, and lived realities of students and other educational stakeholders in $\mathrm{HEl}$. I focus on these very experiences to better understand how formal games education contributes to the formation of professional identities that are conservative, uncritical, and risk-adverse, which is significant given that qualifying for degrees in higher education contexts has become an increasingly mandatory criteria in job postings since it was identified as an entry point into gameswork (Deuze, Martin \& Allen, 2007). Ongoing engagement with education in games is vital for understanding how the future of this creative sector is shaped and structured for its future workers.

\section{Learning to work in games}

The project on which this paper is based addresses these questions, based on critical thematic analysis of qualitative research in $5 \mathrm{UK}$-based $\mathrm{HEI}$ offering suites of games programmes at the undergraduate and postgraduate levels. The mixed methods approaching to exploring these education programs include 49 semi-structured interviews with students instructors, and administrators, observations of the working 
contexts of these participants including labs and exhibitions, and discourse analysis of institutional promotional materials and policy and trade documentation related to higher education in the UK. The case study institutions were selected from a broad range of universities offering games courses for geographic diversity, and diversity of participants was also prioritized in recruitment though ultimately the majority of those who contributed to the study were White British males.

I explore how the normalization of the above-mentioned professional identities are in some part based on how students in games higher education are exposed to ideas about what working in games looks like. A picture of gameswork is formed from various sources across these programmes, including instruction from those working in or previously employed by well-known firms, internships and placements within game companies, and extra-curricular activities such as game jams and networking events enabling meetings with professional game workers. As a complement to these professionalizing or 'employability' activities, students also describe learning about the less favourable elements of gameswork such as crunch, gender pay gaps, curtailed career lengths, and harassment from news media and online discussions. Beyond these increasingly mainstream narratives, instruction within games programmes often overtly refers to the punishing realities of both 'getting into' the industry given the highly competitive nature of most open positions and the brutal expectations normalized for workers once they are in the role (Harvey, 2019).

Based on these norms in games teaching, student working futures are configured in terms of movement and spatiality, evoking particular affective attachments to locale and myths of freedom as well as distancing from factors such as the impacts of Brexit, highprofile media coverage of precarity in games, the normalization of transnational work configurations, and decreasing game job opportunities in the UK. In my research with 'gamesworkers in becoming', students reveal deep anxieties about labour and the industry, but also hopeful narratives about the possibilities afforded by flexibility and transnational flows of production. Indie work in particular is seen as affording opportunities for creative freedoms but also as a route into the mainstream Triple-A industry, an ultimately conservative approach akin to the functioning of hope labour in online social production (Kuehn \& Corrigan, 2013). Myths of freedom are significant for how these young people navigate their working futures and they also inform the subjectivities that are cultivated in discourses about games work, particularly given ongoing emphasis on the diversification of the labour force. In my discussion I conclude by noting what these imaginaries signal for other digital industries- the failure of presuming education as part of a pipeline to work presents its own challenges and constraints.

\section{References}

Chia, A. (2019.) "The Moral Calculus of Vocational Passion in Digital Gaming." Television \& New Media, 20(8), pp. 767-777. 
Consalvo, M. (2008.) "Crunched by Passion: Women Game Developers and Workplace Challenges." In Beyond Barbie \& Mortal Kombat: New Perspectives on Gender and Gaming. Edited by Yasmin B. Kafai, Carrie Heeter, Jill Denner and Jennifer Y. Sun. Cambridge and London: MIT Press, pp 177-191.

Deuze, M., Martin, C.B. \& Allen, C. (2007.) "The Professional Identity of Gameworkers." Convergence, 13(4), pp. 335- 353.

Fung, A. (2016.) "Redefining Creative Labor: East Asian Comparisons." In Precarious Creativity: Global Media, Local Labor, edited by M. Curtin \& K. Sanson. Berkeley: University of California Press, pp. 200- 214.

Harvey, A. (2019.) "Becoming Gamesworkers: Diversity, Higher Education, and the Future of the Game Industry." Television \& New Media, 20(8), pp. 756-766.

Hunteman, N. B. \& Aslinger, B. (Eds.) (2013.) Gaming Globally: Production, Play and Place. Basingstoke: Palgrave.

Kuehn, K. \& Corrigan, T.F. (2013.) "Hope Labor: The Role of Employment Prospects in Online Social Production." The Political Economy of Communication, 1(1), pp. 9-25.

Kerr, A. (2016.) Global Games: Production, Circulation and Policy in the Networked Era. New York and London: Routledge.

Livingstone, I. \& Hope, A. (2011.) "Next Gen: transforming the UK into the world's leading talent hub for the video games and visual effects industries." NESTA. https://media.nesta.org.uk/documents/next_gen_wv.pdf

Neff, G., Wissinger, E. \& Zukin, S. (2005.) "Entrepreneurial Labor among Cultural Producers: 'Cool' Jobs in 'Hot' Industries." Social Semiotics, 15(3), pp. 307-334. 